\title{
Assimilation and Integration Policy for Criminators and Children in Prevention and Control of the Spread of COVID-19 Seen from the Ideas of Private Society in Indonesia
}

\author{
Rugun Romaida Hutabarat ${ }^{1^{*}}$ \\ ${ }^{1}$ Faculty of Law, Universitas Tarumanagara, Jakarta 11440, Indonesia \\ "Corresponding author. Email: rugun@fh.untar.ac.id

\begin{abstract}
In the midst of the current pandemic situation, forcing the government to take steps to issue policies to prevent the spread of COVID-19, which if it occurs in prisons becomes a new problem. One of the policies taken was to free prisoners through the process of assimilation and integration mechanisms. This study was conducted by the author by conducting normative legal research which was carried out based on stipulated statutory regulations and processed into a literature study result. This approach is based on analysis based on logic and existing laws and regulations and draws conclusions that are set out in the form of statements and writing. The results of this analysis give rise to several themes that will be discussed here, namely, the relationship between government policies to expel prisoners through assimilation and integration with overcapacity in prisons, and the impact of the issuance of these policies on society.
\end{abstract}

Keywords: assimilation, integration rights, prisoners, COVID-19 prevention

\section{INTRODUCTION}

Formal verification reveals the unexposed defect that Criminal acts are an inseparable part of human life. Basically, a criminal act is an act that violates the norms prevailing in society and is punishable to anyone who violates the norm. In reference to Chapter 1 part of the Introduction to the Decree of the Minister of Justice of the Republic of Indonesia Number: M. 02-PK.04.10 of 1990 concerning the Patterns of Development of Prisoners / Detainees of the Minister of Justice of the Republic of Indonesia, the current Correctional Institution is based on placing detainees, prisoners, state children and clients of correctional facilities as subjects and viewed with the background of individual citizens to be given guidance, not with a background of retaliation. Based on this principle, the correctional institution is a place to foster prisoners and correctional students with the aim of forming convicted persons to realize their mistakes, improve themselves and to not repeat criminal acts so that they can be accepted back in the community. Therefore, the correctional institution is expected to be able to shape the personality of prisoners who are considered bad in society into a personality that is considered normal and in accordance with the prevailing norms.

This means that anyone who violates the rules, must be held accountable for his actions, and he is subjectable to punishment as a penalty (except for exempted people such as those with mental disorders, underage and under pardon). In general, the purpose of punishment itself is to uphold public order, prevent crimes and provide a deterrent effect on criminals. The idea of punishment in itself is not intended as a method of suffering or degrading human dignity.

In imposing sanctions on perpetrators of criminal law violations, judges do not only have to impose imprisonment. Imprisonment should only be imposed as a last resort sanction (principle of ultimum remedium). Before the Covid19 pandemic, almost all regional offices of correctional institutions in Indonesia experienced overcapacity. Beginning from January 31, 2020, WHO declared that the virus outbreak that occurred in China was a Public Health Emergency or as a Public Health Emergency of International Concern (PHEIC)[1]. Until now, positively confirmed cases of COVID-19 continue to increase every day until they are officially declared a national disaster supported by the issuance of Presidential Decree (Keppres) of the Republic of Indonesia Number 12 of 2020 concerning the Determination of Non-Natural Disasters for the Spread of Corona Virus Disease 2019 (COVID-19). The government has also issued a Government Regulation that regulates large-scale social restrictions contained in Government Regulation Number 21 of 2020 concerning Large-Scale Social Restrictions in the Context of Accelerating the Handling of Corona Virus Disease 2019 (COVID-19), where in the regulation it is 
stipulated that for areas that have many cases of COVID-19 infections must implement large-scale social restrictions through the dismission of all schools and workplaces to do work from home (WFH) and limiting religious activities or other activities in public places or facilities, and implementing Social Distancing and Physical Distancing. Under the condition of overcapacity in Indonesia, the idea of a selective and limitative correctional facility is difficult to fulfill. In addition, there is the issue of implementing social distancing due to the covid19 virus. Due to the condition of prison overcapacity in Indonesia, it is clearly difficult to apply restrictions on activities in prisons, since there is no room for social distancing and physical distancing. This situation will certainly lead to new issues. This has raised concerns for the government about the spread of COVID-19 in prisons and has prompted the government to take the initial steps to prevent the spreads of virus in prison clusters. In this regard, the government finally issued a prisoner release policy in the context of preventing COVID-19. The Minister of Law and Human Rights (Menkumham), Yasonna H. Laoly, stipulated that the policy of releasing prisoners in the midst of this pandemic is an effort made based on the recommendation of the United Nations (UN).

The convicts who are released will go through the assimilation and integration mechanism. Assimilation is the process of fostering prisoners and children by reintroducing them into society in accordance with Regulation of the Minister of Law and Human Rights Number 10 of 2020 and Decree of the Minister of Law and Human Rights Number M.HH-19.PK.01.04.04 of 2020 concerning Expenditure and Exemption Prisoners and Children Through Assimilation and Integration in the Context of Preventing and Controlling the Spread of Corona. This policy follows the common practices by several other countries who have implemented assimilation policies before Indonesia, which includes the United States who released 8,000 prisoners, England and Wales who released 4,000 Iran who released 85,000 prisoners and 10,000 political prisoners. Bahrain frees 1,500 prisoners, Israel 500 prisoners and several other countries which of course also implement this policy [2]. The overcapacity situation makes the ratio of prison officers to prisoners 10:100, meaning that a significant comparison in real conditions does not allow officers to carry out escorts if many of the prisoners are exposed to COVID-19. So far, Menkumham has released approximately 30,000 prisoners. The release of prisoners will be carried out in gradual stages in accordance with the terms and conditions that must be met by the prisoner. There are several categories of serious crimes in which prisoners cannot accept assimilation and integration, such as prisoners with the crimes of terrorism, narcotics and psychotropic drugs, corruption, serious human rights violations (HAM), and organized transnational crimes of foreign nationals.

\subsection{Our Contribution}

This paper provides information regarding the effectiveness of the policy of providing assimilation and integration rights for criminers and children in prevention and control of the spread of covid-19. In addition, it also discusses the idea of correctionalization and the achievement of criminal objectives in this policy and the impact of this policy on society which can add insight to readers and researchers in the future, both Indonesian people and globally around the world who are facing Covid19.

\subsection{Paper Structure}

The rest of the paper is organized as follows. Section 2 introduces the methodology used in this paper. Section 3 presents the result and discussion of Prisoner's Release Policy in the Context of Preventing the Spread of COVID19 is Associated with Prison Overcapacity in Indonesia and the Impact of Assimilation and Integration Policies for Prisoners in the Prevention and Control of Covid-19. Ultimately, all of the analysis will be concluded in Section 4.

\section{METHODS}

The method used is normative legal research, which is to examine legal rules or regulations as a system building associated with a legal event. This research was conducted with the intention of providing legal arguments as the basis for determining whether an event was right or wrong and how the event should be according to law. [3]. This research also uses several approaches, namely the statute approach, which is carried out by examining all laws and regulations that are related to the legal issues being handled [4]. The legal issue handled in this study is the policy of releasing prisoners in the context of preventing the spread of COVID19 related to prison overcapacity in Indonesia. The approach used is a normative juridical approach, done by reviewing or analyzing secondary data consisting of various literatures and journals related to assimilation and integration policies for inmates in overcoming covid-19. The results of this study are descriptive analytical and prescriptive. Analytical descriptive is a research that is carried out descriptively, limited to an effort to reveal a problem and situation as it is, so that it only reveals or describes an event or fact that exists in detail, systematically, and thoroughly while prescriptive is a solution to the legal issue raised and etymologically what it should be [5].

\section{FINDINGS AND DISCUSSIONS}

\subsection{Release of Prisoners Policy in the Context of Preventing the Spread of COVID-19 Related to Prison Overcapacity in Indonesia}

The policy of releasing prisoners during the Covid 19 pandemic aims to reduce the spread of the corona virus. This policy is under the authority of the Ministry of Law 
and Human Rights. The policy issued by the Ministry of Law and Human Rights is based on the government's concern for the spread of the corona virus in prisons. The condition of overcapacity of prisons in Indonesia is the main consideration that a government policy is needed to suppress the increase in the number of Covid19 virus cases. Indonesia is one of the eight countries experiencing extreme overcrowding, along with other countries: Afghanistan, Bangladesh, Cambodia, Nepal, Pakistan, Iran and the Philippines. The number of prisons and detention centers in Indonesia has reached 528 with a capacity of 130,512 people. Meanwhile, the number of prison residents reached 269,846 people.

Overcapacity occurs due to excessive imprisonment, leading to the idea of correctionalization to be difficult to achieve. The placement of imprisonment sanctions seems to be overrated, even though it is clear that in the criminal law system, imprisonment should only be a last resort (the principle of ultimum remedium). In addition, the implementation of prison for prisoners must be done in reference to human rights. In accordance with the criminal law adopted by Indonesia, imprisonment is a form of punishment that can have a deterrent effect on criminals. Prison sentences are often known to be full of torture. However, this concept should not be true, as the main objective of imprisonment is to rehabilitate.

Through the decree issued by the Minister of Justice of the Republic of Indonesia No. 02-Pk.04.10 of 1990 concerning Patterns of Guidance for Prisoners / Detainees, apart from being a place for prisoners to be placed in, prisons also has the objectives, among other things, to be educational and development institutions. The objectives of imprisonment are as follows:

1. As a form of responsibility of the illegal act he has committed.

2. As a manifestation of the injustice that has been experienced by the victim and the victim's family as a result of the actions that have been committed by the perpetrator of the criminal act.

3. In order for the perpetrator to receive guidance in a correctional facility as appropriate and it is hoped that the perpetrator of the crime has an awareness of the wrong that has been committed and provides a deterrent effect in order for the prisoner to not repeat the same act again.

4. Show the public that whoever commits a criminal act will be punished as well, since the law does not differentiate people based on their position.

5. Providing awareness to the public about the consequences received when violating the law.

The existence of imprisonment itself must be seen from various aspects, especially from the aspect that the main objective of the punishment is as a form of protection for society with the aim of preventing, reducing, controlling, and restoring the legal balance that exists in society in resolving conflicts that occur within the scope of society and the aspects of improving human behavioral patterns and life values that previously occurred irregularities in the form of rehabilitation and re-popularization of criminal offenders as well as providing protection to perpetrators from arbitrary laws outside the law. The idea of imprisonment that is given must still be selective, so as to avoid deviations from the norms of morality, religious norms and moral values contained in Pancasila.

The Coronavirus Disease (COVID-19) has been declared a national disaster by the President of the Republic of Indonesia, Joko Widodo, through Presidential Decree No. 12 of 2020 concerning the Determination of Non-Natural Disaster for the Spread of COVID-19. In dealing with this pandemic, the state government, from ministries / agencies to local governments, is asked to work optimally, to exert all efforts and resources available to save the people from the spread of the COVID-19 virus. From March to December 2020, State Civil Servants (PNS), employers, employees, students, and the entire community without exception carry out prevention, independent isolation and carry out all their activities at home (Work from Home) as an effort to prevent the spread of COVID-19. Apart from the community, the government does not forget to take quick action in protecting prisoners who are carrying out guidance.

Through the Indonesian Ministry of Law and Human Rights, a policy was initiated to expel prisoners and children undergoing assimilation at home so that they do not contract the COVID-19 virus while in a prison / state detention center / Special Child Development Institution. As the release policy progressed, many people saw this policy as controversial. This policy is considered to cause new problems, namely an increase in the crime rate. Prisoners and children who get their freedom do not have the guarantee to not repeat their crimes again. Meanwhile, in various media reports, there are many prisoners who have been released seen to be repeating the criminal act again.

This becomes a concern for the community after the prisoner and the child are free. However, no policy is issued without consideration. If seen from the overcapacity condition in almost all regional offices of prisons, it is very likely that they will be affected by this COVID-19 disease. The prison cell which is overcrowded, narrow, and very inappropriate is a worthy consideration for implementing this policy, since the opportunities for infection become very easy and wide. In the midst of the Covid-19 pandemic, prisoners in prions are at a high risk of contracting Covid19. The problem is, apart from many prisons that are unfit for habitation due to the lack of facilities and health counseling, excess capacity also makes social distancing policies impossible to implement. With the existence of policies to free prisoners and children in prisons / remand centers, it is hoped that it can prevent and overcome the spread of Covid19.

Due to obstacles in the form of overcapacity so that guidance carried out in prisons cannot be carried out optimally and effectively, the government is needed to issue policies that are expected as a solution to the overcapacity of prisons. The Indonesian government itself has issued many policies, one of which is to carry out rehabilitation or renovation of buildings to the construction of new buildings with the aim of being able to accommodate more prisoners. However, it can be seen that policies like this are not an 
effective measure to solve problems. This policy is considered to be wrong considering the growth in the number of prisoners who become convicts continues to increase due to the high number of crimes that occur in Indonesian society.

In addition, the government issued a policy on shifting punishment in the criminal justice system, known as Restorative Justice. Restorative Justice strives for a criminal justice system by prioritizing justice for both victims and perpetrators of crimes with alternative laws. Like how the international instruments recommend the use of "alternative to prison" as outlined in the "Custodial and Non-Custodial Measures Alternative to Incarceration" UN New York 2006.

The Restorative Justice approach provides a view from a different angle, that the form of punishment as the fulfillment of the losses suffered by victims of crime and peace is the ultimate goal of this approach method. However, the existence of a criminal shift system does not necessarily abolish or eliminate the prison system. The form of imprisonment is still given to perpetrators of serious crimes such as crimes that kill lives, cause mass losses, terrorism, corruption, etc. where there is no excuse for the act that has been committed. This implication method can also be in the form of penal mediation, namely the process of criminal settlement where by prioritizing peaceful methods by bringing together victims and perpetrators of criminal acts to discuss the settlement that has occurred between them by appointing a neutral mediator by providing legal advice or advice and solutions. This puts forward the restoration of the situation by making peace where justice becomes a benchmark in this method.

Apart from penal mediation, there is a diversion policy in the juvenile criminal justice system which is the same as the form or embodiment of Restorative Justice implementation. This criminal policy has been stated in Law No. 11 of 2012 concerning the Juvenile Criminal Justice System [6] which is obliged to prioritize the restorative justice approach with the diversion method. This is a form of implementation of the protection of children's rights. According to Law No. 11 of 2012 the institutions that function to provide guidance to children are the Child Special Guidance Institution (LPKA), the Temporary Child Placement Institution (LPAS) and the Social Welfare Organizing Agency (LPKS). The main objective of the application of diversion is to protect children from both the community and victims and to avoid negative community judgments by providing guidance outside the criminal justice system by including the role of the wider community.

The government also implements a criminal policy in overcoming the problem of overcapacity, such as by providing clemency, reducing the sentence, remission and assimilation. As is well known, Indonesia is currently being attacked by a pandemic. In the midst of this national disaster condition, Indonesia has a problem of overcapacity of the prisons in Indonesia. Because these two problems are interconnected state problems, in the midst of current conditions, the government is taking advantage of the situation to overcome the problem of overcapacity in Indonesia. The life of prisoners in the middle of a prison is indeed very concerning, the number of prisoners who are placed in the residential room is more than the capacity, hence the free movement of the prisoners is very limited. Seeing in the midst of conditions of prisons with overcapacity up to $200 \%$, of course making the conditional release policy is one of the steps to prevent the spread of Covid-19. The consideration of issuing a parole policy is also based on the human rights of every prisoner to live and obtain health.

In addition, in the midst of overcapacity conditions in prisons make prisoners and prison officers very vulnerable to infection. The right to health of prisoners has also been affirmed in article 12 of the International Covenant on Economic, Social and Cultural Rights, that matters of prevention, treatment and control of all forms of pandemic infectious diseases and other diseases related to work[7]. Therefore, the state as a party to the covenant is required to take steps by issuing policies that ensure prisoners can live properly and obtain proper health facilities. In the context of Covid-19, the state's obligation is to take preventive steps so that transmission can be minimized.

Basically, the provision of assimilation and conditional release in Permenkumham Number 10 of 2020 concerning Conditions for Providing Assimilation and Integration Rights for Prisoners and Children in the Context of Preventing and Combating the Spread of Covid-19 is not much different from the implementation of Permenkumham Number 3 of 2018 concerning Terms and Procedures How to give remission, assimilation, leave nearing release and conditional leave, it's just that the implementation of assimilation in the middle of Covid-19 is carried out at home under the supervision of prison officers online. The government's conditional release is also an urge from the United Nations to release prisoners who are at high risk of contracting Covid-19 because of the pandemic they are facing. Prison is one of the places that is at high risk of spreading Covid-19 where inmates are used to being crowded and gathering. Amid the conditions of overcapacity prisons, of course there is no guarantee that prisoners live in a clean environment.

The policies taken by the government are also a reflection of the policies taken by other countries. The government considers that issuing a release policy for prisoners is an effort that is considered in accordance with human values to avoid the risk of direct transmission. Meanwhile, every prisoner has the right to get proper health services. Health for prisoners / detainees is implemented based on Law no. 12 of 1995 concerning correctional facilities and Law Number 36 of 2009 concerning health. As part of the mandate health service in each prison implementing unit, every prisoner has the right to get proper health services in the coaching process. This service is provided to inmates who need medical attention related to their health condition while in prison. This health service is provided to all inmates in the form of prevention and treatment. Prevention is carried out in order to minimize the spread of disease in correctional institutions / detention. Meanwhile, treatment is an effort to provide health for inmates who are suffering from illness so that the coaching program can run optimally. Conditions also changed with the Covid19 pandemic, where 
social distancing was not possible for assisted residents given the overloaded conditions of prisons.

\subsection{Impact of Assimilation and Integration Policies for Prisoners in the Prevention and Control of Covid-19}

More than 30 thousand prisoners in Indonesia have to be released by the government, in this case the Ministry of Law and Human Rights. The reason is that the detention room is overcapacity which can trigger the spread of the covid19 virus causing thousands of inmates to walk free prematurely. The release of prisoners policy is based on the Covid-19 pandemic outbreak and to prevent the spread of the corona virus in prisons. As we know, the Covid-19 virus is an outbreak that was found in the city of Wuhan, China in December 2019 until it was finally determined to be a global pandemic. To date, out of 222 countries that have been confirmed globally with Covid19 there are 80,453,105 people with a death toll of $1,775,776$ people. This virus is considered very deadly and very easy to spread. With various considerations, many countries have issued regulations related to the release of prisoners, including Indonesia. The release of prisoners is based on the provisions stipulated in the Ministry of Law and Human Rights decision number M.HH-19.PK/01.04.04 regarding the Release and Release of Prisoners and Children through Assimilation and Integration in the Context of Prevention and Combating the Spread of Covid-19.

One of his releases was because prisoners were considered very vulnerable to the spread of the corona virus. Drajat Tri Kartono explained, there are at least 4 possibilities why they acted again [8]:

1. There is no deterrent effect. Punishment is basically used to make perpetrators or lawbreakers experience exclusion. Repressive is not restitutive. Repressive means being oppressed, ostracized, and kept away from family, friends, and the outside world so that they are deterred. Drajat explained, when inmates are in prison there are those who can get along well, get regular food, and other things that actually make life easier. So that inmates feel at home in prison and do not feel deterred.

2. Lack of preparation. There is no preparation for survival in the outside world. Usually before the prisoners are released, there is a process of moderation to prepare him or her to adapt to the world or penalties. What is meant by correctional services is that he returns to society, so that he must follow the norms that exist in society. This process is mediated by the prison. Prison actually has a function to train people, not only to excommunicate, not only repressive but also to train for them so that when they come out, they are ready. There are legal, cultural, economic (including how to find a job), mental, and spiritual preparations. When the prisoners leave with incomplete preparations, the consequence is that they do not experience compliance. The prisoners were expelled because of humanitarian aspects, so that the prisoners did not catch Covid-19. So, according to him, the possibility that the mediation in prison has not been completed or there is no such mediation.

3. Do not have a job and savings. Prisoners do not have jobs because they are detained for a long time in prison. Some have no savings, while some have run out of savings. Except for those who are very rich. According to Drajat, this is where there is a process of stigmatization which then causes them to commit crimes to make ends meet and get recognition.

4. Congenital or inherent traits. A prisoner cannot be deterred because it is a trait or inherited trait that is owned socially and individually. Individually, this means that these qualities have attached to him. Meanwhile, socially, it means that he is influenced by his close friends to commit criminal acts. So that the prisoner looks for free opportunities.

The purpose of punishment is to correct the perpetrator to be good and not to repeat the crime again. The state of Indonesia in implementing its legal politics is based on the basic philosophy of the state, namely Pancasila and the 1945 Constitution. So that in the legal political process the formation of laws and regulations must be very careful to pay attention to Pancasila and the 1945 Constitution so that the resulting legislation products will not be canceled by the Court. The constitution through judicial review results in conflict / disagreement with Pancasila and the 1945 Constitution. Starting from such an understanding of legal politics, it is appropriate to state that the formation of laws is a social process and a political process which is very important and has a broad influence, (laws) will shape and regulate or control society. The laws by the authorities are used to achieve and realize the goals they aspire to[9]. The purpose of punishment in the Draft Criminal Code Concept Sudarto once stated, that in the first objective there is a concluding view of community protection (social defense), while the second objective contains the purpose of rehabilitation and resocialization of the convict. The third objective is in accordance with the view of customary law regarding "adat reactie", while the fourth objective is spiritual in accordance with the First Principle of Pancasila[10].

If starting from the national goal, namely "community protection" or "social defense", the objectives of law enforcement according to Barda Nawawi Arief are:

1. The community needs protection against anti-social actions that harm and endanger the community. Starting from this aspect, the purpose of punishment (criminal law enforcement) is to prevent and overcome crimes.

2. Society is obliged to protect against the dangerous nature of a person. Therefore, criminal / criminal law which aims at correcting crimes or trying to change and influence the community to comply with the law again and become good and useful citizens of society.

3. The community also needs protection against sanctions or reactions from law enforcers and from members of the community in general. Therefore, it is also natural that the situation of preventive prevention must prevent arbitrary treatment or action outside the law (inhuman). 
4. Society needs protection of the balance or harmony of various interests and values that are not affected by crime due to crime, because it is also natural that criminal law must resolve conflicts caused by criminal acts, be able to regulate balance and bring a sense of peace in society [11].

As stipulated in Article 2 of the Correctional Law, the penitentiary system is a series of law enforcement which has the objective of making prisoners aware of their mistakes, improving themselves and not repeating criminal acts so that they can be accepted back by the community, and can play an active role in development, and can live in a sustainable manner. reasonable as a good and responsible citizen. Then the explanation of Government Regulation that the correctional system aims to return the prisoners to be good citizens and to protect the community against the possibility of repeating criminal acts by assisted residents and is an implementation and part of the inseparable from the values contained in Pancasila.[12] Through this correctional system, the implementation of this prison sentence is guided. This penitentiary system is of course in line with the purpose of punishment, namely to improve individuals and criminals themselves, to make people deterred from committing crimes, to make certain criminals unable to commit other crimes.

Regarding the repetition of criminal acts committed by exconvicts who have been released in the context of preventing the spread of Covid19, the role of correctional hall (Bapas) must be further enhanced. Article 1 point 4 of the Correctional Law has stated that Bapas is an institution for carrying out correctional client guidance. Furthermore, the Bapas function is to guide, assist, and supervise the prisoners who receive assimilation or integration. The correctional system is a series of criminal law enforcement units, therefore its implementation cannot be separated from the development of a general conception of punishment. The Correctional System in addition to aims to return the prisoners as good citizens, it also aims to protect the community against the possibility of repeating criminal acts by prisoners in prison.

In the case of the release of more than 30 thousand prisoners due to Covid19, the purpose of punishment should be the benchmark in evaluating who is entitled to assimilation and parole. For the purpose of protecting the public so that they do not feel threatened by released prisoners, it is better if supervision is carried out by the bapas. Supervision should still be done electronically. For example, communicating via video conferencing and whatshap / line groups so that the assimilation and integration program is maintained. With the limited number of Bapas, it is possible to collaborate with legal officials, such as the police and community groups. The police can also coordinate with the Directorate General of Corrections regarding the distribution of released prisoners so that the police can take preventive measures to prevent the occurrence of a crime from recurring.

Release of prisoners to reduce the spread of covid-19 amidst overcrowded prisons is indeed a temporary solution. The main cause of disease transmission in overcapacity detention is the government's policy that still prioritizes imprisonment in law enforcement to provide a deterrent effect for someone caught in a legal case. The large percentage of the use of prisons in statutory regulations and the imposition of crimes is not balanced with adequate facilities and infrastructure. Seeing the complexity of the problems related to imprisonment both from the perspective of its effectiveness, cost problems, overcapacity found in almost all prisons in Indonesia and other negative consequences related to this crime, it becomes very relevant, if in this section it will try to expose what is the policy of implementing the crime of deprivation of liberty in the future. Barda Nawawi Arief recommended an integral policy to address all the complexities of imprisonment implementation problems. The integral policy which should be contemplated includes, among other things, the following problems [13]:

a How to create a causative social policy which is expected to eliminate the causative factors and conditions that give rise to crime (which lead to imprisonment). This is what according to global agreement (in UN Congresses) is often stated as "the basic strategy of criminal policy".

b How to develop an integral policy in implementing selective and limitative policies in the use of imprisonment.

Thus, to overcome the complexity of the problem of imprisonment, both means must be pursued, namely causative social policies and selective and limitative policies on the use of imprisonment. Where the two policies must be integrated with each other or there is an integration between the two. Therefore, it is not right to use only one of the two. Selective and limitative policies in the use of imprisonment must be initiated by formulating it into material criminal law, then proceeding to formal criminal law and finally to criminal law enforcement, especially the implementation of imprisonment. It is necessary to reform the three sub-systems by instilling the basic idea of being selective and limitative in the use of imprisonment.

As long as the government does not change its law enforcement policies in the form of detention and imprisonment, prisons and detention centers in Indonesia will always be congested and at risk of spreading the virus. The problem of overcapacity that occurred in almost all regional offices in correctional institutions in Indonesia should receive special attention, well before the covid19 virus pandemic. There are various factors that influence overcapacity, one of which is the poverty rate of the population in Indonesia. Of course, apart from these factors there are many other factors that can influence the occurrence of a crime. This view is in line with Albert Cohen, where according to him, one or several factors alone cannot be considered sufficient to cause a crime in an individual case, there must be a number of factors that cocreate it [14].

The existence of crimes that occurred during the Covid-19 pandemic, especially those committed by ex-convicts who were released in the context of preventing Covid19, cannot be separated from existing economic problems. The 
government needs to think about a restorative justice approach as an effort to reduce prison overcapacity. The concept of restorative justice is an approach that focuses more on the conditions of creating justice and balance for perpetrators of criminal acts and victims. Of course, this is supported by regulations that no longer prioritize imprisonment. When compared with the amount specified in Book II and Book III regarding the specific gravity of imprisonment and fines (as well as imprisonment) it appears that imprisonment is prioritized to punish the perpetrator of a criminal act. Legislative policies should avoid the formulation of criminal threats that are imperative (ie, single formulation and cumulative formulations). The main weakness of this imperative system is that it is very rigid because it 'requires'. So, the judge is faced with a certain type of crime that is certain and highly mechanical, because like it or not the judge seems to have to determine imprisonment automatically. Judges are not given the opportunity and leeway to determine other types of crimes that are suitable for the accused. Observing such characteristics (i.e. rigid, imperative, definite and mechanical / automatic), it is clear that such a system is evidence of a very striking legacy or influence from the classical school. As is understood, the classical school wants to objectify criminal law from the subjective characteristics of the criminal offender and does not give the judge the freedom to determine the type of crime and the size of the punishment.

The large number of imprisonment charges in the Indonesian Criminal Code [15] also has implications for the implementation of crimes as part of the criminal subsystem. Prison sanctions are the most dominant sanction in the Criminal Code, around $70 \%$ of single imprisonment and the total imprisonment of $98 \%$. The implication in the form of overload in prisons will occur so that the idea of a selective and limitative correctional facility is very unlikely to materialize in the criminal system.

\section{CONCLUSIONS}

1. The provision of assimilation and conditional release in Permenkumham Number 10 of 2020 concerning the Terms of Providing Assimilation and Integration Rights for Prisoners and Children in the Context of Preventing and Combating the Spread of Covid-19 is not much different from the implementation of Permenkumham Number 3 of 2018 concerning Terms and Procedures Providing Remissions, Assimilation, Leave Towards Release and Conditional Leave only for the implementation of assimilation in the middle of Covid19 is carried out at home under the supervision of prison officers online. The government's conditional release is also an urge from the United Nations to release prisoners who are at high risk of contracting Covid-19 because in the midst of a pandemic, prison is one of the places that is at high risk of spreading Covid-19 where inmates are accustomed to living crammed and gathering. Amid the conditions of overcapacity prisons, of course there is no guarantee that prisoners live in a clean environment.

2. Imposing imprisonment with the correctional system is not only intended to protect the community from the dangers of crime but also to protect and provide provisions for people who have lost their way because of committing a crime. But in reality, it is not easy to realize this noble goal because the function of the correctional facility itself is becoming difficult to implement with the covid19 pandemic. Concerns regarding the impact of the prisoner release policy amid the Covid-19 pandemic began to emerge. If we pay attention to the impacts that arise, the release of prisoners should not only prevent Covid-19, but must pay attention to aspects of justice and deterrent effects as the purpose of punishment and the idea of correctional facilities. This is in accordance with the theory of punishment which is not only a retaliation for the wrongdoing of the perpetrator but a means of achieving a useful goal, namely fixing the perpetrator so that he becomes good and not repeating his crime again.

\section{REFERENCES}

[1] A. Zhahrina, "WHO Announces Coronavirus Outbreak as Global Emergency Status, What Does That Mean?"

(https://sains.kompas.com/read/2020/01/31/113000623/ who-umumkan-wabah-virus-corona-berstatus-daruratglobal-apa-artinya?page=all, accessed on 8 October 2020, 11:17)

[2] CNN Indonesia, "Yassona: Release of Prisoners During Corona UN Recommendation" (https://www. cnnindonesia.com/nasional/20200416152520-20-

494204/yasonna-pembebasan-napi-saat-coronarekomendasi-pbb, accesed on 8 October 2020, 12:43)

[3] M. Fajar and Y. Achmad, 2017, Dualism of Normative and Empirical Legal Research, Prints IV, Yogyakarta, Student Library, p. 36.

[4] P. M. Marzuki, Legal Research, Kencana Prenada Media Group, Jakarta, 2011. p.93.

[5] T. S. Kurnia et.al., Legal Education, Law Studies and Legal Research in Indonesia: A Reorientation, Pustaka Pelajar, Yogyakarta, 2013. p.129

[6] Law No. 11 of 2012 concerning Juvenile Criminal Justice System

[7] International Covenant on Economic, Social and Cultural Rights, (https://toolsfortransformation.net/wpcontent/uploads/2017/05/UU_NO_11_2005_hak-hakekonomi-sosial-dan-budaya.pdf. accessed on 16 Desember 2020, 19:24) 
[8]. N. F. Shalihah. "Why Are Assimilated Inmates Criminals Again? This is the Analysis ", via https://www.kompas.com/, accessed on 26 November 2020, 13.00 WIB.

[9] N. S. P. Jaya, Law and Criminal Law in Economics, Diponegoro University Publishing Agency, Semarang, 2012. p.128-129.

[10] Sudarto, Criminal Punishment and Action, BPHN, Jakarta, 1982, p. 4.

[11] B. N. Arief, Purpose and Guidelines for Criminalization, Semarang, Diponegoro University Publishing Agency, 2009, p. 45.

[12] Government Regulation Number 32 of 1999 concerning Terms and Procedures for the Implementation of Correctional Assistance Citizens

[13] B. N. Arief, Several Comparative Problems of Criminal Law, Jakarta, Raja Grafindo Persada, 2003. p.27.

[14] E. H. Sutherland, et.al., Basic Principles of Criminology, Prenadamedia Group, Jakarta, 2018. p.87.

[15] Indonesian Criminal Code 